\title{
Exploring visitors' motivation in heritage festivals. A text analysis perspective
}

\author{
Andrea Moretti - Michela Cesarina Mason \\ Francesco Raggiotto
}

\begin{abstract}
Purpose of the paper: This paper proposes an interpretive framework addressing social network analysis in tourism-cultural organizations, helping to develop a feasible solution for Social Media (SM) analysis within cultural organizations (better fitting the specificities, of the organizations that are culturally closer to their collective mindsets, generally humanistic).

Methodology: An interpretive framework has been developed. Such framework was operationalized by performing Content Analysis using T-LAB software. The empirical analysis was divided in two steps, addressing the same research context (local heritage festival).

Findings: The analysis provides schematization of context classification in SM data analysis, that is potentially generalizable. Basing on empirical evidence, some insights about a) the possible uses of T-LAB, and $b$ ) of the conditions within which to use the software in small cultural/tourist organizations, have been provided.

Research limits: The proposed schematization is tested only on a single empirical context. Generalizability of usage processes of T-LAB, indicated in this paper on SM data analysis requires additional testing in other contexts.

Practical implications: The present work identifies stages and processes that small cultural/touristic organizations can follow to enable an analytic process, with respect to SM data (i.e., texts), using tools better fitting their operational capabilities, degree of complexity and cultural background.

Originality of the paper: The study offers an original framework and mapping of possible analytic tools for analogic and digital data, in small cultural organizations. It also provides a representation of the usage processes of the T-LAB software, with respect to the processing of written contributions, within a consumer behavior perspective.
\end{abstract}

Key words: social media management; cultural tourism; small firms; cultural organization; heritage festival; T-lab

\section{Introduction}

In the last decade, it has become apparent the structural importance, in managing co-production relationships, of adopting Social Media (SM) as an interaction tool, both from the side of consumers and companies (i.e., from a Relationship Marketing perspective). For being such an inescapable process, its management potential appears not to have been completely 
sinergie Vol. 35, N. 103, 2017

exploited by organizations, mainly due to a general underestimation of related, complex, strategic and managerial implications. Few firms are in fact actually able to fully use and interpret SM data related to interaction with stakeholders (e.g., customers). In addition, the required investments (i.e., capabilities, tools, dedicated resources) are inadequate in the majority of firms. This tendency appears even more relevant in those contexts in which experiential production is the core component of organizational activities.

After collocating Social Network Analysis within a more general framework of interpretation, this paper reports the empirical analysis performed on a specific -and with a growing relevance- context: heritage festivals. Within this context, a process of analysis has been developed, specifically adapting it to the research context.

Such an application highlights the importance of considering the cognitive distance between analytic tools and specific decision-making contexts, within a SM Management perspective.

\section{Theoretical Background}

\subsection{The digital and social revolution in marketing}

A framework for Social Network Analysis in tourism and cultural organizations, is certainly grounded on some established research areas. These areas, that have gained an increasing importance as component of an interpretative framework, can be identified as:

- studies on SM Management, SM Marketing, especially within a Relationship Marketing perspective;

- studies on information complexity and organizational decisionmaking.

In the last twenty years, the frenetic development of ICT and Web 2.0 have had profound implications for the business world. In particular, SM and the user-firm interactions allowed by the Web 2.0 have completely reshaped how business relationships are managed (Moretti and Tuan, 2014). SM have exponentially increased the importance of virtual users (Finotto and Micelli, 2010; Kietzmann et al., 2011; Mangold and Faulds, 2009; Mortara and Sinisi, 2012; O’Reilly, 2005; Vernuccio et al., 2012), leading to an entirely new paradigm in knowledge economy (Nonaka 1994, Rullani 2004a, 2004b). Research has emphasized the huge revolution that SM have triggered in marketing, enhancing value co-creation within virtual communities of heterogeneous users (Kornum and Muhlbacher, 2013), and leading to the today well-known SM Marketing. SM Marketing can be considered part of Relationship Marketing (Moretti and Tuan, 2014). This view is highly consistent with the inner aim and meaning of Relationship Marketing itself, whose underlying, basic assumption can be summarized as follows: identifying and nurturing a base of long-term customers appears more profitable than continuously seeking to enlarge customer base with new customers (Reinartz and Kumar, 2003).

Customer Relationship Management (CRM) is considered as one of the most important tools of relationship marketing, allowing a clearer 
understanding of consumer behavior of the market. CRM appears to be intimately related with new technologies. The rise and development of SM has led to Social CRM (SCRM), a merge between traditional CRM and Web 2.0, leading to a model of "customer retention and involvement" (Faase et al., 2011). The engagement that is created between customers and the firm allows a substantial improvement of relationships: an increased engagement means, in fact, interactions that are more meaningful (Wang and Owyang, 2010). In SCRM, the customer-retaining perspective of traditional CRM is integrated with the involvement component, which is strongly related to Web 2.0, in turn oriented towards interaction and exchange between users.

SM introduce new ways in which knowledge is created and shared. Cocreation of knowledge is allowed, and customers can influence others in their networks (Baird and Parasnis, 2011; Greenberg, 2010). SCRM appears to be a crucial tool to stay close to consumers, by monitoring constantly virtual communities in order to predict, and anticipate new and emerging needs and trends, overwhelming competition and reinforcing competitive advantages, especially in fast-moving markets (Woodcock et al., 2011).

Summing up, SM and SCRM can be identified as the highest point within a space of managerial-economic analysis, which increasingly sees a progressive transition from the production of transactional value, towards the production of a more relational value. In such a context, value production itself is shifting from being strictly analogic to being strictly digital.

\subsection{Information complexity and managerial decisions in SME \& Small Organization}

The second stream of research, useful in Social Network Analysis, is represented by contributions, classifying the level of complexity of information structures, and supporting business decision-making processes. Such stream represents a traditional topic in organization studies literature (Costa and Nacamulli, 1993; Rugiadini, 1979).

Information complexity is commonly classified as high or low, according to the following parameters:

- the extent to which information is structured, with respect to the strategic decision-making level (Anthony, 1965). The more structured the information is, the simpler its processing. As information becomes less structured, its complexity increases. Such levels of complexity are generally linked to the level at which decisions are taken (strategic, managerial, operative);

- the width of the spectrum with which information can be used (and the organization is willing to use it). Information collected and employed for well-defined, limited purposes (e.g., single decisions) is generally classified as low-complexity information. Instead, collected information that is used for wide range of purposes (i.e., many decisions in many organizational functions and levels) is commonly classified as highly complex;
Andrea Moretti

Michela Cesarina Mason

Francesco Raggiotto

Exploring visitors'

motivation in heritage festivals. A text analysis perspective 
- in addition, information density (concentration: i.e., the extent to which information is distributed), is often used as an additional measure of information complexity (Bonifacio, Bouquet and Cuel 2002). Accordingly, whereas information is concentrated in terms of articulation and usage, complexity tends to be low; on the other hand, high complexity occurs as information and its use is distributed.

Organizations can consider the above criteria as decision-making conditions that require information processing (i.e., complex, various, variable information). Such processing may be required to support business decisions, and to transform the original information size to a reduced and relevant one (for decision-making).

The relationship between information complexity and organizational dimensions is intimately linked to the topics presented above. Existing literature on firm dimensions (e.g., Di Bernardo, 1997) highlights the importance of adequacy of tools supporting decision-making, to existing organizational processes. In particular, operative information mechanisms (Rugiadini, 1979) must be strongly adequate to the context. An information system (tools and procedures) that is not able to adapt to organizational conditions is totally unuseful. Hence, from this perspective, the use of any information tool or process supporting decision-making requires contextualization.

As far as it is known, academic and professional literature has not yet provided a definitive classification of analytic tools for Social Networks; not identifying, in this way, organizational and information complexities related to the implementation and to the use of such tools. Classifications exist only with respect to the characteristics of analytic tools ${ }^{1}$. In any case, such classifications do not represent an interpretation in terms of the relationship between the complexity of produced information, and supported decisions.

The elements that can be derived by such tools are exquisitely quantitative, and connected with specific online behaviors (e.g., if users "like" something on Facebook), that can be quantified and considered as evaluations or intentions. In a nutshell, such information is not related to the textual content of social networks, but only to actions that are quantified through the typing of specific pre-codified options (i.e. the like button) limiting the width of textual richness.

Instead, the textual content is extremely interesting for management analysis (of social interactions). In order to extract this interpretation value, specific research processes are required, usually based on text analysis (e.g., $\mathrm{NUDE}^{\mathrm{mm}}$, $\mathrm{NVIVO}^{\mathrm{mm}}$, T-Lab ${ }^{\mathrm{mm}}$ ), or data analysis tools (e.g. $\mathrm{R}^{\mathrm{mm}}$, Python $^{\mathrm{m}}$ ), and on analytic data processes (data science).

Both quantitative analysis of likes and text content require a strategic interpretive framework. The most diffused perspective today appears to be the relational perspective, that is pretty tactical, and not strategic (Tuan, 2015), limiting in this way the potential of such tools in terms of business management.

For a more specific classification, see Kevan (2014) https://blog. bufferapp. com/social-media-analytics-tools 
Within this framework, despite the enormous potential that SM offer, the Italian business landscape still appears not to fully understand such opportunities (Moretti e Tuan, 2014): albeit an increasing number of Italian organizations is more present on SM than in the past, they still conceive SM as a sort of "clone" of a corporate website. Furthermore, there are no commonly accepted measures to assess SM marketing strategies (Gillin, 2009); firms can mainly rely to SM and marketing analytics (Lovett and Owyang, 2010).

\section{Festivals as knowledge creation systems}

\subsection{Festivals and Festival organizations: project work of knowledge creation}

The general framework depicted in Figure 1 finds a great relevance in those contexts in which knowledge production is the main factor of the production process. In cultural and tourism productions, festivals wellrepresent those situations (Getz, 2008). Research interest on festivals follows different perspectives of analysis:

- research on events and festivals, (as experiential, cultural and touristic phenomena denoted by economic relevance), and the related organizations involved in managing and developing them;

- studies investigating consumer behavior and motivations in festivals.

National and international festivalization of cultural and touristic production has shown a dramatic growth in the last two decades (Richards, 2007). Such growth has triggered increasing attention from academic and professional literature. Such a strong interest for management and organization of temporary events (i.e., festivals) can be justified by, at least, three reasons:

- the experiential nature of festivals (Pine and Gilmore, 1999; Carù and Cova, 2005; McCarthy, 2013);

- the festival potential, in terms of characterization and positioning effects on tourist destinations (Franch 2002; Prentice, Andersen 2003; Ferrucci et al., 2017);

- the economic relevance of the phenomenon (Argano et al., 2007; Gibson et al., 2010; Long and Robinson, 2004; Trezzini, 1992; Akhoondnejad, 2016).

According to the first perspective, processes of value production show a strong relational characterization. The most important relationships occur between the system of product offering (one or many), participants (that are, in this case, pro-sumers), and other partners (e.g. members, sponsors, other cultural organizations). The intensity of the relationship varies according to the extent to which co-production takes place within different contexts.

Adopting the second perspective, the inclusion in the tourist offering of festivals is clearly identified as a key component of destination positioning, contributing also to determine the identity of the destination.

The economic relevance of the phenomenon has itself stimulated a wide research corpus; from a macroeconomic perspective, and from the point of 
sinergie Vol. 35, N. 103, 2017

view of the impacts of these events (Brown, Var and Lee, 2002; Lee, Taylor 2005). Such development has reached now a strong, established knowledge base, including both methodologies and indicators.

From a managerial point of view, festivals have been characterized mainly by an augmented role of value co-production, in all management stages (pre-festival, festival, and post-festival) and by the important role of "project organizations" (Argano 2005).

During the pre-festival stage, co-production involves strategic (e.g., selection of participants, definitions of the main themes) and operative (e.g., accommodation, communication and promotion) aspects. As the event takes place, co-production occurs as, normally, production and consumption coexist. In addition, strong interactions between the system of offering and participants can be noticed. As the event concludes, (post-festival), co-production may be strongly connected with narrative elements, concerning for example participants' experiences, and Word of Mouth.

The analysis of the three stages of co-production highlights where digitalized co-production can be more relevant in managerial terms. In fact, in all the three stages, interaction management could partially be -or even fully- digitalized. Highly interactive websites, and social tools connected with festival development, management, and narrative processes, exemplify the digitalization opportunities described above. Such virtual places represent a virtual reification of festivals, where their effects perpetuate, develop, and are testified by communities of users; in these knowledge-based processes, knowledge that is produced is characterized by redundancy, recursiveness, multiple usability, which determine, in turn, its value (Rullani, 2004a, 2004b).

On the other hand, such virtual processes and places require increasing resources (i.e., managerial, institutional, relational) as the festival phenomenon, and its reification through these processes, grow.

Project organizations tend to be the majority of organizations in charge of festival management (Argano, 2004). Such organizations are commonly characterized by:

- the variety and variability of organizational dimensions, during the stages of festival development (in any case, micro-organization);

- the predominant role of voluntary work of their members;

- the unique combination of professional and non-professional subjects.

Such conditions lead to increasing difficulties, with respect to structuring and retaining competences and capabilities, useful in pursuing organizational goals. Managerial processes appear problematic too. On the one hand, managing value production processes is denoted by a concentration in terms of time: as the festival takes place, but also extending to the time between one edition and the other, hence requiring increasingly structured resources.

On the other hand, the increasing digitalization of both the production and reification of specific knowledge deriving from festivals, requires two specific resources devoted to a) collection and analysis of the produced knowledge, and b) managing the social interaction with all relevant stakeholders. 
Such conditions are very unlikely to be present within the current configurations of organizations managing festivals. In fact, the majority of them still not appear to be strategically and dimensionally ready to face the challenges described above.

Basing on the above considerations, it is possible to highlight how, within SM Management, festival production is structurally positioned as far from the origin in Figure 1.The level of information complexity increases with the increasing use of SM (in both operative and strategic stages), and with the implementation of the storage festival collective memory within such information infrastructures.

\subsection{Motivation in festivals}

Tourism research has focused strongly on the visitor's motivations. Ralston and Crompton (1988) were among the first to provide a study about the motivation of event participants. Following this seminal contribution, Uysal et al., (1993) were among the first studies to provide an exploration of the dimensions of the visitors' motivation. In general, studies on festival motivation have covered different kinds of festivals, in several countries (e.g., Ralston and Compton, 1988; Uysal et al., 1993; Formica and Uysal, 1996; Lee, 2000; Lee, 2004; Kitterlin and Yoo, 2014). Albeit some similarities in the dimension of motivation that are recurring in those studies, each contribution indicated specific dimensions of festival motivation. Some literature reviews on the topic, like Lee et al., (2004), Li and Petrick (2006), and Thompson and Schofield (2009) provide extensive exploration of festival motivation literature.

Last but not least, it should also be noted how text analysis with respect to tourism management literature appears not to be a popular methodological approach (e.g., Godnov and Redek, 2016). However, the high potential of this tool in tourism research appears high (e.g., see Gretzel et al., 2008).

\section{Research context and methodology}

\subsection{Research context}

“Tempus Est Joucndum" is an heritage festival located in Gemona del Friuli, a small town in northern-east Italy. Since 1992, the event is managed by Pro Loco Glemona, a local non-profit organization. In Pro Loco Glemona, general direction is concentrated in the hands of a permanent committee. Event management and organization are, instead, responsibility of a small group of people (three/four). In particular, those young members are responsible for the artistic and marketing direction of the event. This small group widely increases with volunteers during the event.

The event is more than a simple historical reenactment: it is aimed at going back into the Middle Age, for one weekend, with ancient foods, no modern comforts, and even the use of the ancient currency of Gemona.
Andrea Moretti

Michela Cesarina Mason

Francesco Raggiotto

Exploring visitors

motivation in heritage

festivals. A text analysis perspective 


\section{Sinergie}

Vol. 35, N. 103, 2017

\subsection{Methodology}

\subsubsection{T-LAB}

The entire analysis was carried out adopting the T-LAB software. It offers a unique combination of linguistic, statistical and graphical tools applied to text analysis. The software allows analyzing various texts (e.g., single books or a number of different web posts taken together). After a preliminary, proper text codification by the researcher (for data entry), a number of analysis are allowed, such as:

- perform various kinds of correspondence analysis, and cluster analysis;

- creating semantic maps, in order to identify sequential relationships between words or topics in the text;

- check for the contexts of occurrence of single words;

- analyzing the overall corpus (i.e., the codified text) or just some subsets of it, using different lists of keywords;

- creating various contingency tables or co-occurrence matrixes.

\subsubsection{Methodological steps}

This study adopts an experimental combination of different research methodologies, applied to text analysis. The analysis was divided into two separate steps.

The first step (ex-ante step) was performed analyzing contributions in various online sources. This activity was performed before the festival took place (few weeks before the event).

Selected techniques available in T-LAB were used to explore the most recurring words, and to analyze the most important relations among them. During the ex-ante step, the texts to be analyzed were identified as follows. First, the most common social channels to find events and tourism information in Friuli-Venezia Giulia were identified (e.g., popular blogs or institutional webpages). The seven most popular contributions were selected. The number of Facebook "Likes" was considered as a popularity indicator (see Table 1).

For the ex-ante step, among the tools included in the T-LAB software, were selected those appearing to the researchers as the most significant for the purposes of the study. The T-LAB tools employed in this study were word association, co-word analysis, and comparison between pairs of keywords (co-occurrence analysis). A detailed description of the three tools will be provided infra $\$ 4.1$.

A second, the in itinere step was then performed. During the event, a pen-and-paper questionnaire was distributed among the visitors. The questionnaire was divided into 27 points, addressing different aspects of the event. Items were based on 7-point Likert scales; in addition, respondents were asked to list five major motivations leading them to visit "Tempus est Jocundum". 400 units were surveyed.

The same analysis steps conducted during the "ex-ante" stage were also performed in this step, on the questionnaire data, only with respect to non-structured answers (motivations listed). Results were then compared with those emerged from the ex-ante stage. 
Tab. 1: Contribution and FB Likes of Tempus est Jocundum festival

\begin{tabular}{|l|c|}
\hline Source & $\begin{array}{c}\text { Number of } \\
\text { Facebook } \\
\text { Likes(25.10.2015) }\end{array}$ \\
\hline http://www. turismofvg. it/evento/131553 & 57.892 \\
\hline $\begin{array}{l}\text { http://www. eventifvg. it/site/eventi/tempus- } \\
\text { estjocundum-2015.html }\end{array}$ & 29.097 \\
\hline $\begin{array}{l}\text { http://www. udine20. it/gemona-tempus-estjocundum-la- } \\
\text { rievocazione-medioevale-30-lug2-ago-2015/ }\end{array}$ & 26.372 \\
\hline $\begin{array}{l}\text { http://newsmedievali. blogspot. it/2015/07/tempusest- } \\
\text { jocundum-2015-gemona-del. html }\end{array}$ & 24.263 \\
\hline $\begin{array}{l}\text { http://www. girofvg. com/tempus-est-jocundumpalio-del- } \\
\text { niederlech-e-dama-castellana-gemonadel-friuli-ud/ }\end{array}$ & 11.596 \\
\hline $\begin{array}{l}\text { http://www. fogliogoriziano. com/tempolibero/gemona- } \\
\text { medioevale/ }\end{array}$ & 4.780 \\
\hline $\begin{array}{l}\text { http://www. youfolklore. it/tempus-est-jocundum-2015- } \\
\text { gemona-del-friuli/ }\end{array}$ & 2.912 \\
\hline $\begin{array}{l}\text { http://www. portalenordest. it/conoscere/costume- } \\
\text { etradizioni/ rievocazioni-sagre-fiere-feste-emanifestazioni/ } \\
\text { tempus-est-jocundum-rievocazionestorica-a-gemona-del- } \\
\text { friuli }\end{array}$ & 285 \\
\hline
\end{tabular}

Source: our elaboration

\section{Results}

\subsection{The ex-ante step}

\subsubsection{Word association}

In order to check for the most frequent word associations that occur in the selected web contributions, radial diagrams have been developed. The word "medievale" (medieval) was the most recurring word (19 times). The second most recurrent word was "Gemona". For both, a subjective analysis has been performed.

Such analysis brought to the definition of some clusters, obtained primarily by observing words referring to the same subject. Clusters can be defined as a number of elementary contexts, characterized by a pattern of keywords, and described by the most representative lexical units. Following this procedure, the analysis of the word "medievale" led to the following graphical representation:
Andrea Moretti Michela Cesarina Mason Francesco Raggiotto Exploring visitors' motivation in heritage festivals. A text analysis perspective 


\section{sinergie} Vol. 35, N. 103, 2017

Fig. 1: Associations with the word "Medievale"

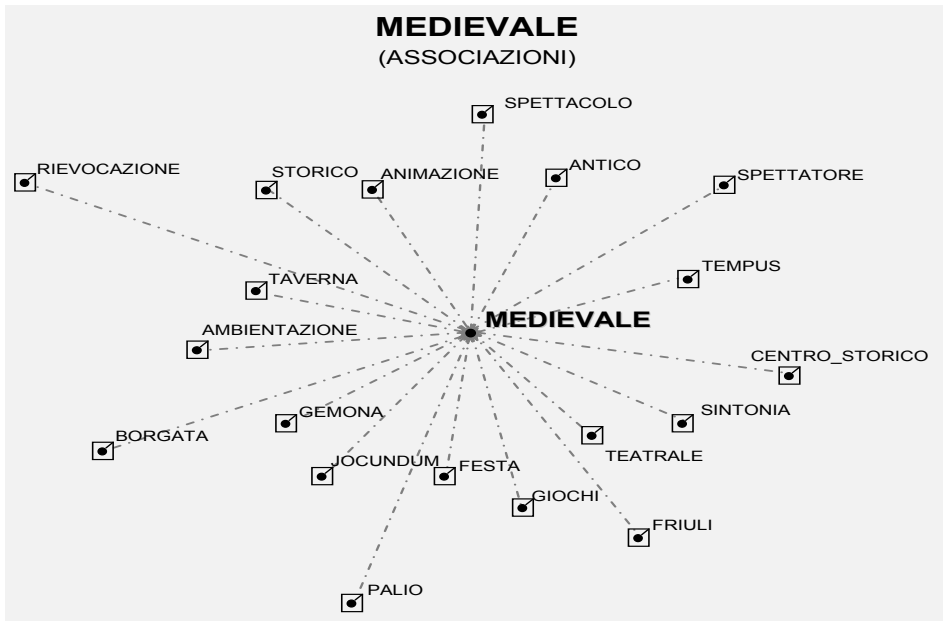

Source: own elaboration

Subjective analysis identified three clusters:

- "storia" (history), grouping the lemmas "antico" (ancient), "Tempus" (festival's name), "Joucndum" (festival's name), "rievocazione" (reenactment), "storico" (historical);

- "Intrattenimento" (entertainment), grouping "spettacolo" (show), "spettatore" (audience), "sintonia" (harmony), "teatrale" (theatrical), "giochi” (games), "festa” (celebration), "palio" (historicaly tapestry), "Borgata” (small village), "tavern" (tavern);

- "Luogo" (place), grouping "centro storico" (old town center), "Gemona”, "Friuli", "ambientazione" (location).

Figure 3 shows the radial diagram for the word "Gemona".

Fig. 2: Associations with the word "Gemona"

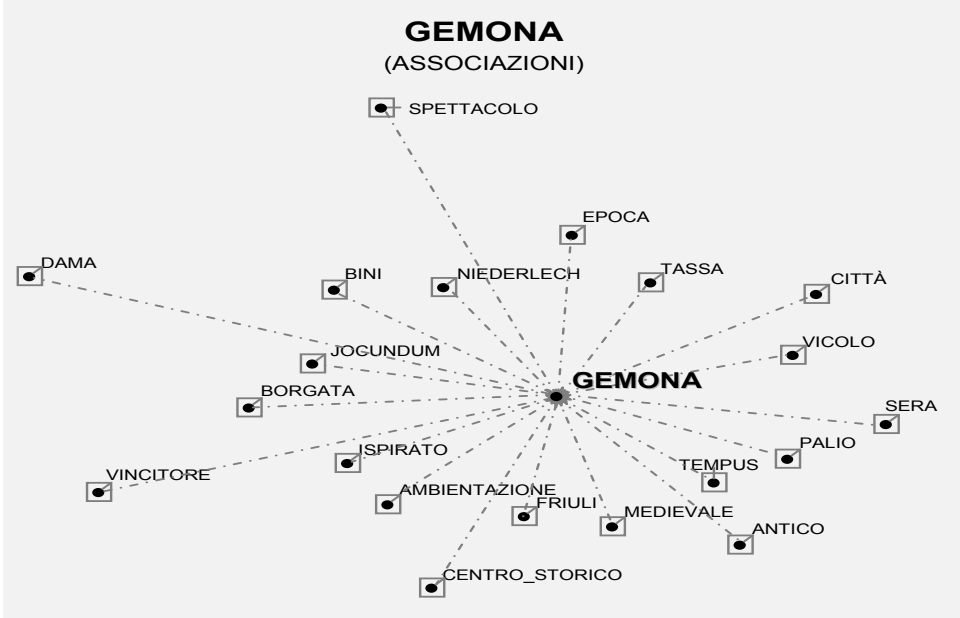

Source: own elaboration 
The same procedure was followed, leading to the identification of the following clusters:

- "Storia" (history), grouping "epoca” (historical age), "tassa” (tax), "Tempus", "antico" (ancient), "medievale" (medieval), "Jocundum", "Niederlech" (a kind of medieval tax);

- "Intrattenimento" (entertainment), grouping "spettacolo" (show), "palio", "ambientazione" (location), "ispirato" (inspired), "vincitore" (winner), "Borgata", "dama” (lady), "Niederlech";

- Luogo (place), grouping "città" (city), "vicolo" (alley), "sera” (evening), "Friuli", "centro storico", "Bini" (Via Bini is the street in which the festival takes place).

Looking at the above figures, it can be noticed the emphasis given by the authors of the analyzed contributions to the historical and cultural value of the festival, together with the spectacular nature of the whole event, involving visitors in a number of ways: by tasting ancient food, providing highly evocative shows and games, and so on.

In addition, location is also strongly emphasized. The festival is in fact carried out entirely within the historical area of the town, and only in the evening.

\subsubsection{Co-word analysis}

The second analysis carried out during the ex-ante step is co-word analysis. T-LAB analyzes similarity matrixes by using a number of statistical techniques, allowing to represent the relationships between entered data, within a reduced space (Multidimensional Scaling, MDS). In order to better provide a representation of the relationships between lexical units, T-LAB adopts the Sammon method: through the computation of an association index, the software identifies the proximity values of the processed data. Proximity values are typically square matrixes, allowing the interpretation of the relationships between objects (proximity/distance).

The stress function measures the correspondences between the MDS map and the input matrix: the lower the level of stress, the higher the goodness of fit. In this analysis, a value lower than 0.10 has been considered as an indicator of goodness of fit. In this case, the value was 0 . 606 , indicating an optimal goodness of fit.

Co-word analysis (Figure 3) confirms the willingness of the producers of analyzed online contributions, to promote the festival emphasizing the word "medioevo", and highlighting some peculiar aspects of the event, such as the absence of modern food, the fact that the event takes place in the town center and the reenactment of medieval challenges.
Andrea Moretti

Michela Cesarina Mason

Francesco Raggiotto

Exploring visitors'

motivation in heritage

festivals. A text analysis 


\section{sinergie}

Vol. 35, N. 103, 2017
Fig. 3: The dominant words in co-word analysis

MDS (METODO SAMMON); STRESS $=\mathbf{0} .0606$

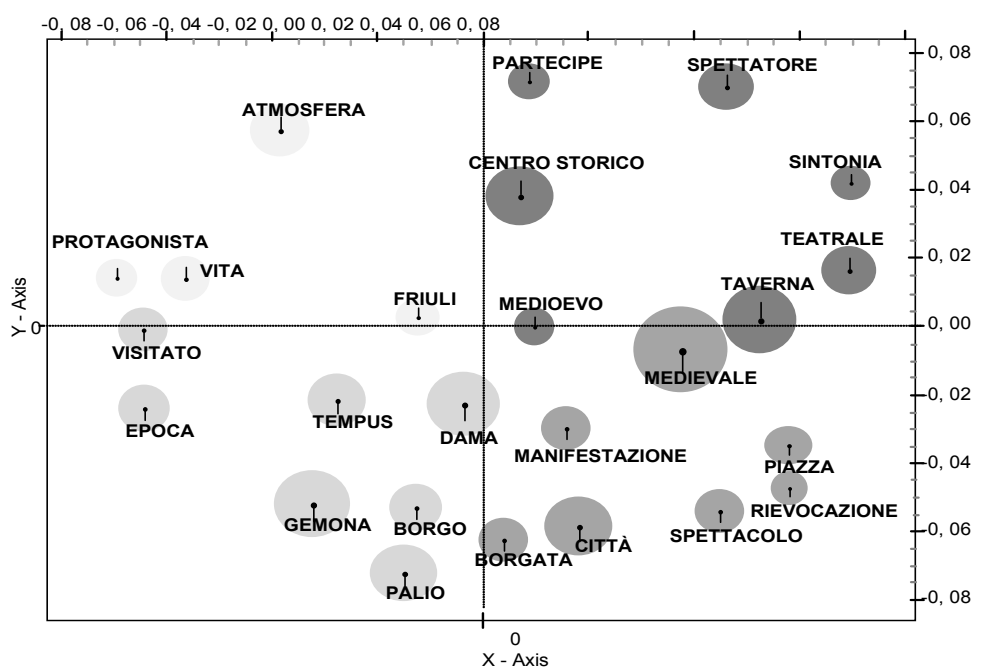

Source: own elaboration

\subsubsection{Comparisons between pairs of keywords}

The final type of analysis performed in this stage of the study compares couples of keywords. In order to perform this analysis, the researcher needs first to choose the lemmas to take into consideration. According to the results of both co-word analysis and word association, the most recurring words "medieval" and "Gemona" were chosen. The lemmas with the most relevant co-occurrence are "Palio", "Niederlech", and "Festa".

A specific T-LAB feature allows us to analyze the percentage with which every lemma develops co-occurrence relationships with the two lemmas that are mostly used:

- "Festa" is mostly associated to "Medievale" 62.5\%, (the festival is by definition a medieval event);

- "Festa" is also sometimes associated (12.5\%) to "Gemona". This indicates the perception of a complete involvement of the town in the event (the town is perceived as a component itself of the overall event, not just a location)

- Finally, "Festa" is also associated to both lemmas together (25\%), indicating that, the event is also perceived as a good occasion for having a good, fun time, regardless of its historical and cultural value. Finally, the ex-ante step of the analysis shows at least four "thematic nuclei". First, the historical aspects of the festival; secondly, the spectacular nature of the event (recreating the rivalry among different groups of local inhabitants); finally, the presence of several artists entertaining visitors, and the peculiar location (the town of Gemona, illuminated only by torches). 


\subsubsection{Word association}

Francesco Raggiotto

Exploring visitors'

motivation in heritage

festivals. A text analysis

Also in this case, radial diagrams were built for the most recurring perspective lemmas. In this case, "divertimento" (amusement) represents the most common motivation. .

In this case, three clusters can be identified:

- "Evasione" (distraction), including the lemmas "spettacolo" (show), "musica" (music), "festa", "giochi" (games), "amico" (friend), "compagnia" (company of people), "convivialità" (conviviality);

- "Gastronomia" (gastronomy), containing "mangiare" (eat), "cibo" (food), "mellitum" (a particular wine sold during the event), "chiosco" (vending stand), "cucina" (cuisine), "taverna" (tavern), "enogastronomia" (gastronomy);

- "Luogo" (place), containing "storia" (history), "appartenenza" (belonging), "tradizione" (traditions), "abitudine" (habits), "passato" (past), "Friuli".

Note that, despite the different semantic area, the identified clusters are the same:

- "Evasione" (distraction), containing the lemmas (entries) "vacanza" (holiday), "evento" (event), "visita" (visit), "partecipazione" (participation), "cultura”, "passatempo", "passione”, "interesse”, "divertimento", "atmosfera", "immersione";

- "Gastronomia", including "cibo" and "sapore";

- "Luogo", including "passato", "medioevo", "usanza”, "costume”, "tradizione", "fuoco", "colori".

It can be noted the strong need, among participants, to find some distractions from everyday life. They see the historical reenactment as an ideal occasion to take some a break from everyday life (as suggested by the lemmas "immersione", "distrazione", "convivialita”"). There is also a strong interest towards gastronomy, perceived as an additional occasion of distraction.

It is also worth to note the frequent use of the lemmas "Friuli", "appartenenza", "tradizione", indicating a strong sense of belonging to the local community, to the Region, and to the town and the event themselves.

\subsubsection{Co-word analysis}

As mentioned earlier, co-word analysis consists in analyzing similarity matrixes and in the representation of relationships in a defined space (Multidimensional Scaling, MDS).

In this case, the value of stress (goodness of fit) is 0,0835 . Note that it is slightly higher than the same value in the ex-ante step. This could be justified by the different typology of texts that has been considered (in the in itinere case, single words reported in questionnaires from a random sample of respondents).

"Storia" and "Divertimento" are the most recurring lemmas in the "motivations" section of the questionnaire. Such lemmas are also the most relevant with respect to the relationships between lexical units. 
sinergie Vol. 35, N. 103, 2017

Note the presence of the word "atmosfera" (atmosphere), one of the most influential lemmas (entries) in the co-word analysis. In this case, atmosphere can be considered as the historic atmosphere or as the right atmosphere to have some fun.

As in the ex-ante step, also here this part of the analysis took into consideration the most recurring lemmas.

The word "atmosfera" atmosphere is related to both words, singularly and with the two words put together. This confirms how the term "atmospheric" has a double meaning, both in historical terms and in terms of pure amusement and distraction.

Albeit $60 \%$ of the cases present "atmosphere" as related with lemmas that are different from those considered in the analysis, $40 \%$ of the cases shows a relation between "atmosphere" and one (or even both) the lemmas considered in the analysis. This means that, at least 160 units (of the total 400) have associated the word "atmosfera" to the word "divertimento", "storia", or both of them.

\section{Discussion}

\subsection{Analytical aspects in a cultural/touristic context}

Discussion can be articulated on different levels.

From a content analysis point of view, combinations of words developed in the ex-ante and in the in itinere steps are coherent with the most important contributions on cultural festival motivations.

According to the results reported throughout this paper, the importance of the historical connotation of the event, together with the peculiarity of the geographical location are both confirmed by the two steps. In addition, motivational analysis has shown a strong sense of belonging not just from the point of view of local inhabitants, but also from the point of view of visitors coming from different Italian regions. Finally, motivational analysis shows the strong role played by the gastronomy.

The choice of splitting the analysis into two, separate stages has allowed to stress some relevant aspects.

First, content categorization of texts in SM, using simplified text categories, allows the researchers to better identify the entity and the articulation of the phenomena to be analyzed. In addition, the possibility to verify during the in itinere step the correspondence between text categories and the results of questionnaires allows to stratify the analysis into more layers.

Such stratification leads to different effects. On the one hand, it offers the possibility for the SM Manager to classify (especially during periods far from the "days of festival") all the information produced and detected using frameworks that the organization can understand (i.e., cognitively closer). On the other hand, checking for the correspondence between actions performed by the organization and participants' perceptions is allowed.

Additionally, the process of analysis performed using the T-LAB software is characterized by a high level of "frugality". This term refers to 
the possibility to obtain more information for decisions with less resources (e.g., with respect to data science processes). This is possible for, at least, two reasons: first, because of the possibility for the organization to use logic categories to classify texts, closer to organization's cultural categories (reduced cognitive distance); secondly, because of the possibility to translate results in such a way that they can be communicated to the members of the organization, without further interpretation or translations by other subjects.

Frugality is coherent with the organizational context of touristic/ cultural organizations connected to festivals. Frugality can be even more relevant in those micro-organizations in which tangible and intangible resources might be extremely limited. In other words, in those microorganizations (i.e., pro-loco) in charge, in some cases, of highly complex events, the frugal connotation of analytical processes might be required in order to match with the available human and technological resources. Given the culturally-driven nature of such organizations, it is useful to underline the structuring potential of such tools in terms of an institutionalized representation of the relationships occurring between organizations and their relevant value systems (Grandinetti and Moretti, 2004).

Finally, the research confirms the managerial complexity of using SM data, in absence of any strategic perspective to connect them with.

In the case of the present analysis, results and their analysis have not been able to modify the organizational perception of the phenomenon, just leading to the approval of the organizational member (marketing director) in charge of the initiative. The information produced has been considered as useful for all decisions; however, this information has not been actually used in the decision making process.

\subsection{Implications for future research}

Firstly, confirmation about the importance of the content and place aspects with respect to festival motivations, and the small dimensions generally associated to organizations managing cultural festivals, call for a more in - depth analysis of, whether, in managing a SM presence of such organizations should remain autonomous or not, and how this presence could be organized.

As Tuan and Moretti (2015) pointed out, small organizations usually hire part time, freelance SM Managers. It could be interesting, from this point of view, to deepen if cultural and touristic organizations tend to acquire such services following hence a vertical integration logic (i.e., the same SM Manager is employed by several organization within the same territory), or if they pursue a more horizontal-integration logic (a single SM Manager is used by many organizations, involved in managing festivals of the same kind).

In both cases, the analysis of the tactical (strategic) articulation of the use of SM could allow a deeper, more structured understanding of the phenomenon, with respect to current contributions, especially in terms of information complexity. 


\section{sinergie}

Vol. 35, N. 103, 2017

\section{Conclusions}

This paper enriches the consumer behavior literature by applying an innovative approach of analysis, in a very specific tourism context. At the same time, important managerial and practical implications are embedded.

Taking together the results of the two steps of research allows to provide some insights in understanding whether the web actually influence tourists' choices or not.

It is easily understandable that Web 2.0 appears to be an essential tool for tourism promotion. The proposed analysis also shows the importance of integration. Developing a strong social presence of an event goes far beyond developing and updating a profile in the most relevant social networks. The analysis provided in this paper shows the importance of a strong interconnection between editorial planning, content management, and SM management. The key to success, especially for smaller realities (e.g., cultural events in small communities) relies in developing a smart cultural promotion that starts before the event, being part of a wider editorial project aimed at reaching the highest possible number of users. A great deal of effort should be devoted in attempting to actively involve users, by establishing living communication channels, stimulating continuous exchange of opinions and information, trying to establish enduring relationships through feedback loops.

Such a strategy requires time, resources and capabilities that, in some small, limited realities may not be available. In addition, data sources cannot be actually affordable for small, voluntary organizations responsible for event management.

Building on such problems, this paper has tried to provide an affordable methodological/technical approach to develop, especially in small contexts, powerful insights to improve promotional and marketing actions. The techniques used in this paper are not just affordable in terms of costs and resources needed, but at the same time, they present an additional advantage. Semantic analysis does not require extensive capabilities and resources to be performed (like traditional market analysis), rather it allows a certain degree of autonomy to users (i.e., the possibility to use tools and procedures without extensive knowledge). In addition, such kind of analyses allows more room for casualty, allowing users to pay attention more easily to weaker signals and focusing on the element of more interest. Clearly, this kind of analysis presents a huge shortcoming, limiting its scope: analyzing only contributions in Italian might provide a limited perspective, not taking into consideration potential foreign visitors.

Semantic analysis applied to social network allows also enlarging the scope of tourism professionals that can potentially use this powerful tool to assess consumers' motivations. Given the huge number of tourism professionals tend to have a humanistic background, quantitative, and statistical methods can be difficult to manage and apply. This leads, in turn, to losing a possible source of competitiveness (analyzing consumer motivation), unless great efforts (in terms of investments) are devoted. Albeit a very elaborated semantic analysis might result even more complex than traditional statistical analyses (e.g., cluster analysis), it is believed that 
the use of T-LAB might allow to tailor the tools and the steps of analysis to the specific capabilities and objectives of small organizations. This unique feature of the software suggests the huge practical valence of this tool, in terms of decision-making support in these specific organizational contexts.
Andrea Moretti Michela Cesarina Mason Francesco Raggiotto Exploring visitors' motivation in heritage motivation in heritage
festivals. A text analysis

\section{References}

AKHOONDNEJAD A. (2016), "Tourist loyalty to a local cultural event: The case of Turkmen handicrafts festival", Tourism Management, vol. 52, pp. 468-477.

ANTHONY R.N. (1965), Planning and control systems: a framework for analysis, Harvard Business School, Boston.

ARGANO L. (2004), La gestione dei progetti di spettacolo. Elementi di project management culturale, Franco Angeli, Milano.

ARGANO L. (2007), "Alcune coordinate per lo sviluppo dello spettacolo dal vivo in Italia", in Grossi R., (a cura di), La cultura per un nuovo modello di sviluppo, Quarto Rapporto Annuale Federculture, Allemandi, Torino.

ARGANO L., BOLLO A., DALLA SEGA P., VIVALDA C. (2005), Gli eventi culturali, Franco Angeli, Milano.

BAIRD C.H., PARASNIS G. (2011), "From Social Media to Social CRM: reinventing the customer relationship", Strategy and Leadership, vol. 39, n. 6, pp. 27-34.

BONIFACIO M., BOUQUET P., CUEL R. (2002), "The role of classification(s), in distributed knowledge management", in Proceedings of $6^{\text {th }}$ International Conference on Knowledge-Based Intelligent Information Engineering Systems \& Allied Technologies (KES’2002), Special Session on Classification.

BROWN M.D., VAR T., LEES. (2002), "Messina Hof Wine and Jazz Festival: an economic impact analysis", Tourism Economics, vol. 8, n. 3, pp. 273-279.

CARU' A., COVA B. (2005), "The Impact of Services Elements on the Artistic Experience - The Case of Classical Music Concerts", International Journal of Arts Management, vol. 7, n. 2, Winter.

COSTA G., NACAMULLI R.D. (1993), (a cura di), Manuale di organizzazione aziendale, Utet, Torino.

CRISCI F. (2014), "Il nostalgico passato del Festival di Avignone: il pubblico 'in azione' tra teatro popolare e politica culturale", in De Biase F. (a cura di), I pubblici della cultura. Audience development, audience engagement, Collana "Pubblico, professioni e luoghi della cultura", Franco Angeli, Milano, Cap. 22, pp. 375-418.

DI BERNARDO B. (1997), La dimensione d'impresa: scala, scopo, varietà, Franco Angeli, Milano.

FAASE R., HELMS R., SPRUIT M. (2011), "Web 2.0 in the CRM domain: defining social CRM", International Journal Electronic Customer Relationship Management, vol. 5, n. 1, pp. 1-22.

FALCONE P., MORETTI A. (2004), "Il prodotto festival: glocalizzazione artisticoculturale nei contesti”, in Grandinetti R., Moretti A. (a cura di), Evoluzione manageriale delle organizzazioni artistico-culturali. La creazione del valore tra conoscenze globali e locali, Franco Angeli, Milano.

FERRUCCI L., SARTI S., SPLENDIANI S., RODRÍGUEZ M.C. (2017), "Enhancing the Tourism Image of Italian Regions Through Urban Events: The Case of Steve McCurry's Sensational Umbria Exhibition", in Bellini N., Pasquinelli C. (a cura) Tourism in the City (pp. 235-245), Springer International Publishing, Berlino. 
FINOTTO V., MICELLI S. (2010), "Web e made in Italy: la terra di mezzo della comunicazione d'impresa", Mercati e Competitività, n. 4, pp. 101-119.

FORMICA S., UYSAL M. (1996), "A market segmentation of festival visitors: Umbria Jazz Festival in Italy", Festival Management and Event Tourism, vol. 3, n. 4, pp. 197-207.

FRANCH M. (2002), Destination management. Governare il turismo tra locale e globale, Giappichelli, Torino.

GETZ D. (2008), “Event tourism: Definition, evolution, and research”, Tourism Management, vol. 29, n. 3 pp. 403-428.

GIBSON C., WAITT G., WALMSLEY J., CONNELL J. (2010), "Cultural Festivals and Economic Development in Nonmetropolitan Australia", Journal of Planning Education and Research, vol. 29, n. 3, pp. 280-293.

GILLIN P. (2009), The New Influencers: A Marketer's Guide to the New Social Media, Quill Driver Books, Sanger, CA.

GODNOV U., REDEK T. (2016), "Application of text mining in tourism: Case of Croatia", Annals of Tourism Research, vol. 58, pp. 162-166.

GOLINELLI G.M. (2010), Viable Systems Approach, Governing Business Dynamics, Kluwer-Cedam, Padova.

GRANDINETTI R., MORETTI A. (2004), "Verso una teoria manageriale del valore dell'arte e della cultura nei contesti territoriali", in Grandinetti R., Moretti A. (a cura), Evoluzione manageriale delle organizzazioni artisticoculturali. La creazione del valore tra conoscenze globali e locali, Franco Angeli, Milano, pp. 1-34.

GREENBERG P. (2010), “The impact of CRM 2.0 on customer insights", Journal of Business and Industrial Marketing, vol. 25, n. 5, pp. 410-419.

GRETZEL U., XIANG Z., WÖBER K., FESENMAIER D.R., WOODSIDE A.G., MARTIN D. (2008), “Deconstructing destination perceptions, experiences, stories and internet search: text analysis in tourism research", Tourism management: analysis, behaviour and strategy, pp. 339-357.

KIETZMANN J.H., HERMKENS K., McCARTHY I.P., SILVESTRE B.S., (2011), "Social Media? Get serious! Understanding the functional building blocks of Social Media", Business Horizons, vol. 54, n. 3, pp. 241-251.

KITTERLIN M., YOO M. (2014), "Festival Motivation and Loyalty Factors", Tourism and Management Studies, vol. 10, n. 1, pp. 119-126.

KORNUM N., MÜLBACHER H. (2013), "Multi-stakeholder virtual dialogue: introduction to the special issue", Journal of Business Research, vol. 66, n. 9, pp. 1460-1464.

LEE C., TAYLOR T. (2005), "Critical reflections on the economic impact assessment of a mega-event: the case of 2002 FIFA World Cup", Tourism Management, vol. 26, n. 4, pp. 595-603.

LEE C. (2000), "A comparative study of Caucasian and Asian visitors to a cultural Expo in an Asian setting", Tourism Management, vol. 21, n. 2, pp. 169-176.

LEE C.K., LEE Y.K., WICKS B.E. (2004), "Segmentation of festival motivation by nationality and satisfaction", Tourism Management, vol. 25, n. 1, pp. 61-70.

LI X., PETRICK J.F. (2006), "A review of festival and event motivation studies", Event Management, vol. 9, n. 4, pp. 239-245.

LONG P., ROBINSON M. (2004), Festivals and Tourism: Marketing, Management and Evaluation, Sunderland, Business Education Publishers Limited. 
LOVETT J., OWYANG J. (2010), Social Marketing Analytics. A framework for measuring results in Social Media, Altimeter Group, downloaded from www. web-strategist. com.

MANGOLD W.G., FAULDS D.J, (2009), "Social Media: the new hybrid element of the promotion mix", Business Horizons, vol. 52, n. 4, pp. 357-365.

MASON M.C., MORETTI A., RAGGIOTTO F. (2016), Heritage Festival Motivation: Three Medioeval Festival in Nord Est Italy, (mimeo), (forthcoming).

MCCARTHY B. (2013), "The landscape of music festivals in Australia”, in Music Business and the Experience Economy (pp. 119-134), Springer, Berlin Heidelberg.

MORAN P., GHOSHAL S. (1996), "Bad for Practice: A critique of the Transaction Cost Theory”, Academy of Management Review, vol. 21, n. 1, pp. 13-47.

MORETTI A., TUAN A. (2014), "Social media marketing and relationship marketing: revolution or evolution? A first step analysis", Sinergie, n. 93, pp. 115-137.

MORTARA A., SINISI V. (2012), “Tecno-mamme e Social Media nella relazione con il brand: un'indagine esplorativa", Micro and Macro Marketing, n. 2, pp. 273-285.

NOOR AL-DEEN H., HENDRICKS J.A. (2012), Social Media: usage and impact, Lexington Books, Plymouth.

O'REILLY T. (2005), What is Web 2.0?, O’Reilly Media Inc. retrieved from http:// oreilly. com/web2/archive/what-is-web20. html.

PRENTICE R., ANDERSEN V. (2003), "Festival as Creative Destination", Annals of Tourism Research, vol. 30, n. 1, pp. 7-30.

RALSTON L.S., CROMPTON L.J. (1988), "Motivation, service quality, and economic impact of visitors to the 1987 Dickens on strand emerging from a mail-back survey", Report number 3 for the Galveston Historical Foundation.

REINARTS W.J., KUMAR V. (2003), "The impact of customer relationship characteristics on profitable lifetime duration", Journal of Marketing, vol. 67, n. 1, pp. 77-99.

RICHARDS G. (2007), "The Festivalization of Society or the Socialization of Festival? The Case of Catalunya", in Richards G. (ed), Cultural Tourism: Global and Local Perspective, The Haworth Press, Londra.

RUGIADINI A. (1979), Organizzazione d’impresa, Giuffrè, Milano.

RULLANI E. (2004a), La fabbrica dellimmateriale. Produrre valore con la conoscenza, Carrocci, Roma.

RULLANI E. (2004b), Economia della conoscenza. Creatività e valore nel capitalismo delle reti, Carroci, Roma.

THOMPSON K.J., SCHOFIELD P. (2009), "Segmenting and profiling visitors to the Ulaanbaatar Naadam Festival by motivation", Event Management, vol. 13, n. 1, pp. 1-15.

TREZZINI L. (1992), "Festival: realizzazioni e risorse in Italia", in Bodo C., Trezzini L., Turci M.C. (a cura di), L'impatto economico dei finanziamenti pubblici alla cultura: spettacolo dal vivo e festival, Editoriale Scientifica, Napoli.

TUAN A., MORETTI A. (2015), “The Managerial Work of Social Media Manager: an Empirical Investigation in Italian Companies, Communication Agencies and Freelances", in Tuan A., Bridging the gap between social media marketing and corporate social responsability communication, $\mathrm{Ph}$. D Thesis, University of Udine.
Andrea Moretti

Michela Cesarina Mason

Francesco Raggiotto

Exploring visitors'

motivation in heritage

festivals. A text analysis 
UYSAL M., GAHAN L., MARTIN B. (1991), "An examination of event motivations: A case study", Festival Management and Event Tourism, vol. 1, n. 1, pp. 5-10. VERNUCCIO M., CECCOTTI F., PASTORE A. (2012), "L'innovazione nella comunicazione integrata di marketing secondo gli attori del network. Una lettura con le mappe cognitive", Sinergie, n. 88, pp. 93-113.

WANG R., OWYANG J. (2010), "Social CRM: the new rules of relationship management", Altimeter Group retrieved from http://www. altimetergroup. com/2010/03/altimeter-report-the-18-use-cases-of-social-crm-the-newrules-of-relationship-management. html.

WOODCOCK N., GREEN A., STARKEY M. (2011), "Social CRM as a business strategy", Database Marketing and Customer Strategy Management, vol. 18, n. 1, pp. 50-64.

\section{Academic or professional position and contacts}

\section{Andrea Moretti}

Full Professor of Management

University of Udine - Italy

e-mail: andrea.moretti@uniud.it

Michela Cesarina Mason

Assistant Professor of Management

University of Udine- Italy

e-mail: michela.mason@uniud.it

\section{Francesco Raggiotto}

$\mathrm{Ph}$. D. Student in Actuarial Sciences

University of Udine - Italy

e-mail: raggiotto.francesco@spes.uniud.it

sinergie 